\title{
Mobbing of the top predator: a correlation between avian community richness and the number of mobbing species
}

\author{
Paulina Pawlak $^{1}$ D $\cdot$ Zbigniew Kwieciński $^{2}$ Jan Hušek ${ }^{3,4}$ (D)
}

Received: 17 November 2018 / Revised: 21 March 2019 / Accepted: 25 March 2019 / Published online: 5 April 2019

(c) The Author(s) 2019

\begin{abstract}
Mobbing is an anti-predator strategy initiated by one or more members of prey species aiming at driving away a predator that is not undertaking an attack. Because of a continuous dispute as to whether mobbing of a top predator may indicate species richness, we tested the correlation between the number of species engaging in mobbing and avian community richness. In the boreal forest of central Norway, we conducted a series of 83 bird census trials in 2014 and 2015. Each census trial consisted of two 5-min phases. In the first phase an ordinary point count was performed as a control; in the immediately following second phase either a stuffed Eagle Owl or Capercaillie female decoy was presented to study mobbing of a top avian predator and non-predatory species. Mobbing was more likely to occur, and the number of species that engaged in mobbing was higher, in habitats richer of bird species. Our study showed that the cumulative effects of being mobbed increase with richness of the local avian community. We did not find any support for the notion that mobbing is triggered by mobbing activity of the two most active and abundant species. No support was provided for an assertion that using an owl decoy would result in higher number of detected species during a census. Our study urges the need for identification and quantification of costs of mobbing for an avian predator.
\end{abstract}

Keywords Bird census $\cdot$ Boreal forest $\cdot$ Community $\cdot$ Eagle Owl $\cdot$ Mobbing $\cdot$ Species richness

\section{Zusammenfassung}

Mobbing des Top-Prädators: eine Korrelation zwischen der Vielfalt der Vogelgemeinschaft und der Anzahl der mobbenden Arten.

Mobbing ist eine Strategie gegen Prädatoren, die durch ein oder mehrere Angehörige einer Beuteart initiiert wird, mit dem Ziel, einen Prädator zu vertreiben, der selbst nicht angreift. Aufgrund einer anhaltenden Diskussion darüber, ob das Mobbing eines Top-Prädators Artenreichtum anzeigt, haben wir den Zusammenhang zwischen der Anzahl an Arten, welche Mobbing ausüben, und der Vielfalt der Vogelgemeinschaft untersucht. In den borealen Wäldern Zentralnorwegens führten wir in 2014 und 2015 insgesamt 83 Begehungen zur Erfassung des Vogelbestands durch. Jede Begehung bestand aus zwei 5-MinutenPhasen. In der ersten Phase wurde ein einfaches Punktzählverfahren als Kontrolle durchgeführt. In der direkt darauf folgenden zweiten Phase wurde entweder ein ausgestopfter Uhu oder ein weibliches Auerhuhn als Lockvogel aufgestellt, um das Mobbing eines Top-Prädators bzw. eines Nichtprädators zu untersuchen. In Habitaten mit größerem Vogelartenreichtum trat Mobbing mit höherer Wahrscheinlichkeit und einer höheren Anzahl an mobbenden Arten auf. Unsere Studie zeigte, dass die kumulativen Auswirkungen des Gemobbt-Werdens mit der Vielfalt der lokalen Vogelgemeinschaft anstiegen. Wir konnten keinen Hinweis dafür finden, dass Mobbing durch die Mobbing-Aktivität der zwei aktivsten und häufigsten Arten ausgelöst wurde. Die bestehende These, dass die Nutzung eines Eulen-Lockvogels möglicherweise zu einer höheren Anzahl

Communicated by F. Bairlein.

Electronic supplementary material The online version of this article (https://doi.org/10.1007/s10336-019-01662-x) contains supplementary material, which is available to authorized users.

Extended author information available on the last page of the article 
an festgestellten Arten während einer Bestandserfassung führte, konnte nicht unterstützt werden. Unsere Studie unterstreicht die Notwendigkeit, die durch Mobbing verursachten Kosten für den Prädator zu identifizieren und zu quantifizieren.

\section{Introduction}

Mobbing is widely perceived as an anti-predator strategy seen mostly in birds (Curio 1978; Caro 2005). It includes a wide range of behaviours such as vocalisation, warning sounds, inspection of a potential threat and even a direct attack. It may serve to defend nests, offspring and territories (Caro 2005), and also to teach offspring or conspecifics about potential dangers (Curio 1978; Pitman et al. 2017). Other functions may include self-defence, intraspecific signalling of status and fitness, or even the attraction of other mobbers (Slagsvold 1984; Gehlbach and Leverett 1995).

Mobbing may be a signal for a predator that it has been detected and also to force it to leave its place (Curio 1978). Studies have shown that the more a predator is exposed or the more actively it is hunting, the more it increases its vulnerability to being mobbed (Pavey and Smyth 1998; Sunde et al. 2003; Hendrichsen et al. 2006); however, it was shown that a predator can minimise the risk of being mobbed by choosing a cryptic location (Hendrichsen et al. 2006).

There is discussion of whether mobbing may be considered an altruistic behaviour. A reciprocal altruism, as defined by Trivers (1971), was indicated in some hypotheses attempting to explain the phenomena of mobbing (Curio 1978; Frankenberg 1978); however, it is not necessarily the reason for predator harassment in all species (Ostreiher 2003).

Costs of mobbing include an increased risk of death, in particular by being hunted down, higher stress level (Sordahl 1990), energy consumption connected with the mobbing activity, less time spent foraging, eggs and nestlings cooling in case of nesting birds, and many more potential costs that require further investigation (Winkler 1994).

With the great costs of mobbing also come great benefits. As the main benefit, predatory defence seems to be particularly important (Caro 2005). Mobbing is intended to distract, intimidate or expel a predator from a given area (Curio 1978; Pettifor 1990; Flasskamp 1994). Teaching offspring the appearance of a predator, together with parental care, self-defence and mate defence, constitutes a list of significant benefits, explaining the importance and need for mobbing activities (Curio 1978; Shields 1984).

As in other vertebrates, mobbing in birds is rarely known to cause predation (Sordahl 1990). Nonetheless, Micrastur falcons use a hunting technique called provoked mobbing (Smith 1969). They provoke mobbing behaviour in prey birds and catch one of the appearing mobbers. Except this special case of Micrastur falcons, mobbing usually spoils the hunting prospects of a predator in various ways. The predator presence and identity may be exposed to all members of the community; additionally, it may be distracted from hunting, its feathers may be soiled with faeces of some species such as thrushes, its diet may be shifted to less preferred prey, the stress level may increase, and it may even be killed during an act of mobbing (Pettifor 1990; Pavey and Smyth 1998; Caro 2005; Hendrichsen et al. 2006; Templeton and Greene 2007; Courter and Ritchison 2010; Randler and Förschler 2011; Consla and Mumme 2012). Moreover, moving from one place to another in order to find an appropriate hunting spot without mobbers is energy- and timeconsuming, especially during the breeding season (Sunde et al. 2003; Hendrichsen et al. 2006).

To clarify fitness consequences of mobbing for an avian predator, it is vital to better understand the interplay between the costs and benefits of being mobbed. One could expect that the importance of this interplay increases in places with many potential mobbers, which is in habitats with higher species richness. Here we test the prediction that the number of species engaging in mobbing correlates positively with avian community richness. Second, we test the notion that tendency to join the mob by other species in the community is triggered by mobbing activity of the most common and active mobbing species.

\section{Materials and methods}

\section{Study area}

We conducted the study in a valley at an elevation of $250-600 \mathrm{~m}$ a.s.l. near Evenstad, Norway $\left(61^{\circ} 25^{\prime} \mathrm{N}, 11^{\circ} 05^{\prime} \mathrm{E}\right)$. Landscape consisted of a mosaic of agriculture, sparse settlement and cultivated forests on the hill slopes dominated by Norway Spruce (Picea abies) and Scots Pine (Pinus sylvestris).

\section{Census trials}

We performed series of bird census trials. Census points were located randomly within the study area. We defined minimum distance between census points as $1 \mathrm{~km}$ to avoid repeated detection of the same resident birds, and no point was used more than once in order to avoid a positive reinforcement (Knight and Temple 1986). We conducted 
all trials from 06:00 to 10:00 am between 15.4.2015 and 15.6.2015, and a limited pilot study between 5.7.2014 and 9.7.2014. Trials were not conducted on days with poor weather, because of low bird activity and to avoid damage to the decoys. The same three persons performed all census trials.

Each census trial consisted of two phases, lasting $5 \mathrm{~min}$ each. Both phases of a census trial were always performed by the same observer. During the first phase, ordinary bird census trial was performed, i.e. all birds seen or heard were recorded. In the second phase, either a stuffed Eagle Owl (Bubo bubo) decoy, representing a top avian predator of the area, was used as an experimental treatment to provoke mobbing behaviour in resident birds, or a stuffed Capercaillie female (Tetrao urogallus) decoy, representing a common non-predatory species, was used as a control treatment. The stuffed Eagle Owl specimen was mounted permanently on a $1.5 \mathrm{~m}$ wooden pole, whereas the Capercaillie decoy was mounted permanently on a flat Styrofoam bottom. The Eagle Owl decoy was placed in a visible location within the census point (experimental treatment), while the Capercaillie decoy was set onto a prominent place (control treatment). Both decoys were placed in a wide variety of habitats that were available in the research area and where both the Eagle Owl and the Capercaillie were known to reside. After placement of the decoys but before starting the census of the second phase, both decoys were covered with a green cloth for about $2 \mathrm{~min}$. The cloth was removed when no potential mobber was observed within a radius of $50 \mathrm{~m}$ from the decoy and to avoid responses in birds provoked by the cloth itself (Cawthorn et al. 1998). No mobbing behaviour was recorded while the cloth was covering the decoys.

The second phase of the census trial started immediately after removing the cloth from a decoy. In 2015, we recorded all birds seen or heard and all those engaged in mobbing. In the limited pilot season of 2014, we only recorded birds engaged in mobbing. Following Hendrichsen et al. (2006), we defined the beginning of mobbing as the time when the first resident bird was performing mobbing behaviour on the Eagle Owl decoy within a distance of $10 \mathrm{~m}$ from it. We considered the following behaviour as mobbing: (1) emitting mobbing and alarm calls, and (2) aggressive behaviour including flitting towards the decoy (without touching the decoy, only flying slightly above or near it) and direct attacks on the decoy.

Sometimes a bird stopped its mobbing behaviour, but stayed within $10 \mathrm{~m}$ from the Eagle Owl decoy to resume its mobbing activities after a while. A bird that stopped mobbing but remained in an area within $10 \mathrm{~m}$ from the decoy and did not engage in other behaviours such as foraging or singing, was still considered to be mobbing.

Fifty census trials ( 25 trials for each the experimental and control treatment) were carried out in 2015 , and 33 census trials with experimental treatment only were performed in 2014.

\section{Statistical analysis}

We used Spearman's coefficient of correlation to compare numbers of species detected in different phases of the census trials. We tested whether the number of species engaged in mobbing depended on the community richness by running a logistic regression model on the data from 2015 and Poisson regression on the data from 2014. In 2015, in all but one census trial, only one species engaged in mobbing in each trial, if mobbing occurred at all (see "Results"). Hence, we considered logistic regression as an appropriate method to model whether or not mobbing occurred in the census trial as a binary response variable, and included the number of species detected during the second phase of the trial as an explanatory variable. We preferred using the number of species detected during the second phase over the total number of species detected during both phases of the trial, because some of the species detected in the first phase, i.e. before exposure of the Eagle Owl decoy, may have already been gone by the time the second phase began. However, the results were consistent even when the complete number of species detected during both phases of the census trial was used as an explanatory variable. In 2014, mobbing was much more common (see "Results"). Hence, we preferred Poisson regression to model the number of species engaged in mobbing during the trial as a response variable and included the number of species detected during the complete census trial as an explanatory variable (i.e. number of species detected in the first phase + number of mobbing species in the second phase).

Last, we tested whether the fact that one of the keenest mobbing species was engaged in mobbing had any effect on other species joining the mob. We included mobbing activity of the Great Tit or Chaffinch, i.e. whether or not at least one individual of either species was mobbing, as a binary explanatory factor in the Poisson regression run on 2014 data. We ran $\chi^{2}$ tests to test the significance of explanatory factors included in the models. Fit of the best model was checked by the deviance goodness of fit test. All calculations were performed in R 3.5.0.

\section{Results}

\section{Main experiment in 2015}

During a total of 50 census trials in 2015,39 species were detected from which five species (Common Swift Apus apus, Common Raven Corvus corax, European Kestrel Falco tinnunculus, European Crested Tit Lophophanes 
cristatus, Coal Tit Periparus ater) were detected only after the owl decoy was presented, and one species (Green Sandpiper Tringa ochropus) was detected only after exposition of a Capercaillie decoy. The mean number of individuals detected during the first and second phases of the census trial with experimental treatment was 4.92 (confidence interval 4.32-5.51) and 4.52 (CI 3.96-5.08), respectively, and the difference was statistically significant $\left(r_{\mathrm{s}}=0.47, p=0.02\right)$. The corresponding numbers for the census trials with control treatment were 4.36 (CI 3.90-4.82) and 3.96 (CI 3.59-4.33) for the first and second phases, respectively, and again, the difference was statistically significant $\left(r_{\mathrm{s}}=0.74, p<0.001\right)$. The mean number of species detected in the second phase of the census trial did not differ between census trials with experimental and control treatment $\left(r_{\mathrm{s}}=-0.21, p=0.15\right)$.

We recorded mobbing in 11 out of 25 census trials with experimental treatment. In all trials but one, only one species was observed mobbing, with two mobbing species in one trial. Great Tit (Parus major) was observed mobbing in four out of 12 trials, Chaffinch (Fringilla coelebs) in six out of 23, Northern Bullfinch (Pyrrhula pyrrhula) in one out of three, and European Robin (Erithacus rubecula) in one out of seven trials (Online Resource 1). Mobbing/ alarm calls were the most common mobbing behaviour (observed in all four species engaged in mobbing, Online Resource 1). We observed flitting towards the decoy in two instances only, both in the Great Tit. We did not observe any instance of direct attacks on the owl decoy. Other responses that were observed following exposure of the Eagle Owl decoy, not classified as mobbing, included flying away (one instance observed in each the Great Tit Parus major, Song Thrush Turdus philomelos, European Kestrel Falco tinnunculus and two in the Chaffinch Fringilla coelebs), and silence for a period from a few seconds (observed in one trial in a group of birds consisting of two Goldcrests Regulus regulus, one Fieldfare Turdus pilaris, two Great Tits Parus major, and three Chaffinches Fringilla coelebs) for up to 1 min (one instance observed in Winter Wren Troglodytes troglodytes). No mobbing of any type was observed during exposure of the Capercaillie decoy (Online Resource 1).

The logistic regression model on whether mobbing occurred in the second phase of the census trial, with the number of species detected during the second phase of the trial as an explanatory variable, was slightly better supported than the null model, indicating reasonably good fit to the data $\left[\chi^{2}(d f=1)=3.88, p=0.049\right.$; Fig. 1]. The model predicted increased probability of at least one species exhibiting mobbing behaviour from 0.07 , when there were two species observed in the second phase, to 0.84 when there were 10 species observed (Table 1, Fig. 1).

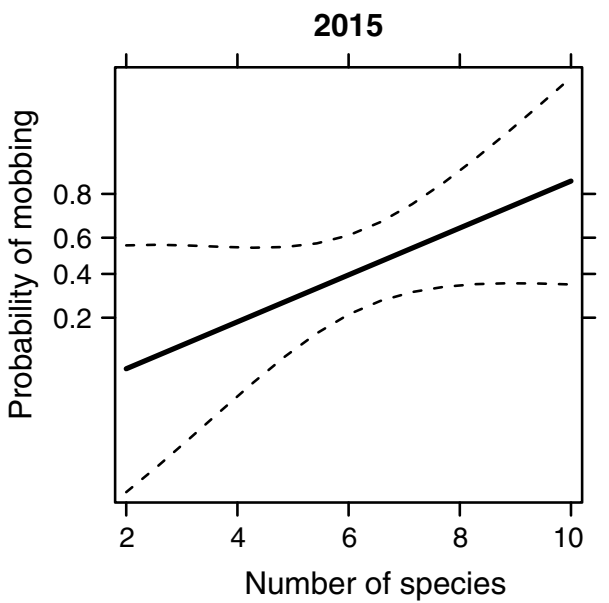

Fig. 1 Relationship between number of species detected during the second phase of the census trial, i.e. after exposure of the Eagle Owl decoy, and probability of at least one species mobbing the decoy. Data from 2015, Evenstad, Norway. Shown is the model fit with $95 \%$ confidence intervals

\section{Pilot study in 2014}

During a total of 33 census trials with experimental treatment, 56 species were detected, from which seven species (Winter Wren Troglodytes troglodytes, Long-tailed Tit Aegithalos caudatus, Mistle Thrush Turdus viscivorus, Sand Martin Riparia riparia, Tree Sparrow Passer montanus, Dunnock Prunella modularis, Common Crossbill Loxia curvirostra) were detected only after the owl decoy was presented. The mean number of individuals detected during the first phase for experimental treatment was 5.97 (CI 5.43-6.51). During the first phase of the census trial with the experimental treatment, the presence of the Great Tit $\left(r_{\mathrm{s}}=0.50, p=0.003\right)$, but not Chaffinch $\left(r_{\mathrm{s}}=0.08, p=0.67\right)$, correlated with the overall number of species detected.

Mobbing was observed in all 33 census trials with experimental treatment in 2014. The mean number of mobbing species in the trial was 4.45 (CI 3.83-5.08) and the mean number of mobbing individuals 6.15 (CI 4.51-7.80, $\min =1$, $\max =22$ ). Altogether, 38 species exhibited mobbing the owl decoy by emitting mobbing/alarm calls or by showing signs of aggressive behaviour (Online Resource 1).

Poisson regression model on the number of mobbing species in the second phase of the trial, with the number of species detected during both phases of the census trial with experimental treatment as an explanatory variable was supported over the null model $\left[\chi^{2}(d f=1)=10.81\right.$, $p=0.001$; Fig. 2]. Including mobbing activity of Great Tit and Chaffinch as a binary explanatory variable was not supported [Great Tit: $\chi^{2}(d f=1)=0.49, p=0.49$, Chaffinch $\chi^{2}$ $(d f=1)=0.70, p=0.40]$. The final model fitted the data well $\left[\chi^{2}(d f=31)=11.85, p=0.99\right]$. The fitted final Poisson 
Table 1 Results of the best selected (1) logistic regression model on the effect of the number of species detected after exposition of the Eagle Owl decoy ("No. species exposition") on whether mobbing occurred or not (dataset from 2015), and (2) Poisson regression model on the effect of the avian community richness ("No. species complete trial") on the number of species engaged in mobbing (dataset from 2014)

\begin{tabular}{llrrrr}
\hline Model/dataset & Explanatory variable & $\beta$ & SE & $z$ value & $p$ \\
\hline Logistic regression/2015 $^{\mathrm{a}}$ & Intercept & -3.29 & 1.79 & -1.83 & 0.07 \\
& No. species exposition & 0.67 & 0.38 & 0.08 \\
Poisson regression/2014 & b & Intercept & 0.49 & 0.32 & 1.75 \\
& No. species complete trial & 0.11 & 0.03 & 3.41 \\
\hline
\end{tabular}

Data from Evenstad, Norway

${ }^{\mathrm{a}}$ Null deviance of the model $=22.66$ on $32 d f$, residual deviance $=11.85$ on $31 \mathrm{df}$

${ }^{\mathrm{b}}$ Null deviance of the model $=34.30$ on $24 d f$, residual deviance $=30.42$ on $23 d f$

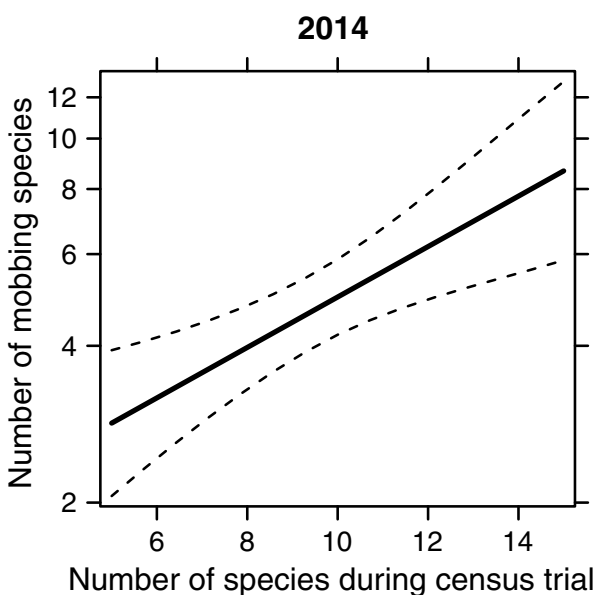

Fig. 2 Relationship between number of species detected during both phases of the census trial, i.e. number of species in the first phase + number of mobbing species after exposure of the Eagle Owl decoy, and number of mobbing species. Data from 2014, Evenstad, Norway. Shown is the model fit with $95 \%$ confidence intervals

regression model (Table 1, Fig. 2) predicted increase in number of species engaged in mobbing from on average 2.8 when there were five species detected during the census trial, to 8.7 when there were 15 species detected.

\section{Discussion}

Prey abundance and diversity is one of the important factors attracting the presence of raptors and owls in an area. The apparent relationship between the presence of an avian predator and the richness of an avian community may be underlined by various ecological factors, including among others the benefit of the rich prey community in enabling prey switching for the predator. This and other possible links behind this relationship have been hotly debated (Sergio et al. 2006, 2008; Martín and Ferrer 2013). Using a total of 58 census trials with exposure of the stuffed Eagle Owl decoy, we demonstrate that, on average, mobbing is more likely to occur in habitats richer of bird species and that there is a positive relationship between the number of species in the community and the number of species that engage in mobbing. This finding implies an increase in, either or both, costs and benefits of mobbing for an avian predator in richer prey communities.

Interestingly, our analysis did not provide any support for the induction of mobbing in the community by mobbing activity of either of the two most common and active species in the study area, Great Tit and Chaffinch. Mobbing calls can induce a mobbing reaction in members of the same or different species, even if birds cannot directly see the mobbed individual (Altmann 1956; Zimmerling and Ankney 2000; Langham et al. 2006; Dutour et al. 2017). In general, mobbing behaviour is a phenomenon common in all sectors of the prey community, except perhaps large species such as the Mute Swan (Cygnus olor) which are mostly free from predation risk (Caro 2005). From the prey's perspective, the most often cited explanation for whether a given bird or species may join in mobbing is the identified predation risk for the mobber itself or for its offspring (Montgomerie and Weatherhead 1988; Dugatkin and Godin 1992a; Caro 2005). Whether size, strength, aggressiveness or other properties of the mobbing species act as a trigger, alone or in interaction - if at all —with other species around the predator, to join the mob remains to be elucidated. It is also known that the same species might be provoked to mob more at locations where a predator more often resides than in areas without an apparent long-term presence of a predator (Sandoval and Wilson 2012).

We used linear models to study the relationship between the richness of the avian community and the number of mobbing species. Whether this simple linear relationship holds also in areas with richer avian communities, such as those in the tropics, remains to be scrutinised. In fact, an indefinite increase in the number of species may not be expected, simply because not all species engage in mobbing or mobbed predator may leave the area before the number of mobbers 
is too high. In that case the relationship would rather be nonlinear.

Our findings highlight the fact that harassment of the avian predator by mobbing by other species from the community is higher in species richer communities. Whether this has any bearing on stress level, behavioural changes and ultimately on fitness of the avian predator remains a topic for future elucidation. As our aim was to study composition of the mobbing community, the exposure of the Eagle Owl decoy for 5 min likely captured well the initial phase of mobbing (Caro 2005). Yet, our results may still be underestimation of mobbing intensity. Combination of visual and auditory signals increased the probability of mobbing of the stuffed Eastern Screech Owl (Otus asio) in a study from the eastern USA (Chandler and Rose 1988). On the other hand, the mobbing intensity of the Common Cuckoo ( $\mathrm{Cucu}$ lus canorus) in western Poland did not depend on whether it was moving or vocalising (Tryjanowski et al. 2018). The short period of exposure of the owl decoy used in our study and the lack of any behavioural response by the decoy may explain the lack of physical attack by mobbers in our study. In addition, although the Eagle Owl is one of the apex avian predators in the studied community, it may not be recognised as the most eminent threat deserving direct physical attack by many small avian species (Donázar et al. 1989).

Generally, mobbing was less common than expected. It occurred in only $52 \%$ of census trials with experimental exposure of the Eagle Owl decoy in 2015, with only one species engaging in mobbing in all trials but one. Also, only two mobbing behaviour categories, namely mobbing calls and flitting towards the decoy, were observed. In 2014, mobbing occurred in all 33 census trials with experimental treatment, and many more species composed the mobbing community. In 2015, when only four species were observed mobbing, the study was performed earlier in the breeding season, while it was done later during the breeding cycle in 2014, when a total of 38 species were observed mobbing. The study was performed in the same study site in both years, leaving the only apparent difference to be accounted for by the timing of the study in relation to the stage of the breeding cycle (Altmann 1956; Shields 1984; Krams and Krama 2002).

Our conclusions may be flawed because of two factors that could not be fully controlled. Firstly, a fieldworker may have acquired a kind of a search image for certain species during the first phase of the census trial, resulting in higher probability of detecting these species in the second phase of the trial. In a North American Bird Breeding Survey in the USA, this appeared as a minor issue (Boulinier et al. 1998). Secondly, the number of detected species increases with time, which may confound the effect of decoy presentation. A formal experiment would be necessary to separate the confounding factor of time and the presentation of a decoy on the number of species detected, but we argue that these issues appear as of minor importance. First, our objective was to study mobbing behaviour and not to describe complete composition of the avian community. Second, we could describe well the bird species present at the spot in just a few minutes and third, the general decrease in number of species detected in the second phases of trials, irrespective of the treatment, suggested that there was not many birds left undetected by us.

If mobbing behaviour caused bias in detectability of avian species between sites occupied and not occupied by predators (Kéry et al. 2008; Sergio et al. 2008), one could expect a stronger correlation between the presence of a certain predator and avian species richness (Ozaki et al. 2006; Sergio et al. 2006; Roth and Weber 2008; Jenkins et al. 2013; Burgas et al. 2014). Despite the tendency in our study to detect fewer species in the second phase of the census trial with exposure of Capercaillie decoy compared to the one with exposure of Eagle Owl in 2015, the difference was not statistically nonsignificant, perhaps because only few species engaged in mobbing in that study year. In any case, our study is not in line with studies which reported that human mimicking or playback of mobbing calls while performing the census resulted in higher species detectability (Gunn et al. 2000; Zimmerling and Ankney 2000; Turcotte and Desrochers 2002; Langham et al. 2006).

True costs are those that handicap fitness either affecting survival or reproduction (Dugatkin and Godin 1992a; Caro 2005). Evidence is at best insufficient for other predators being attracted by mobbing activity and even less supportive for direct killing of the mobbed predator (this study, Slagsvold 1982; Sunde et al. 2003; Sandoval and Wilson 2012). It is further not clear whether other responses to being mobbed exhibited by raptors carry real costs beyond mere irritation (Pavey and Smyth 1998; Sunde et al. 2003; Consla and Mumme 2012). Indeed, during the breeding season moving away from the hunting ground as a result of mobbing may by costly in terms of lost time and energy that could have been devoted to hunting, but it has not been documented whether hunting prospects or efficiency are in fact seriously hampered by moving to a new site or by occupying alternative habitats (Pettifor 1990; Sunde et al. 2003; Hendrichsen et al. 2006). There may even be some benefits to being mobbed by a wider community of birds. This is because many mobbing species may be hunted during the mob, hence providing a predator with easy forage. Moreover, the predator may obtain information of what potential prey species there are in a certain environment (Montgomerie and Weatherhead 1988; Dugatkin and Godin 1992b).

We conclude that the analysis and identification of costs and benefits of being mobbed for an avian predator is an essential next step needed to shed light on the thesis that raptors should occupy sites with higher prey diversity. 
Acknowledgements We thank Professor Piotr Tryjanowski for his kind help with the fieldwork and his comments on the previous versions of the manuscript.

Open Access This article is distributed under the terms of the Creative Commons Attribution 4.0 International License (http://creativeco mmons.org/licenses/by/4.0/), which permits unrestricted use, distribution, and reproduction in any medium, provided you give appropriate credit to the original author(s) and the source, provide a link to the Creative Commons license, and indicate if changes were made.

\section{References}

Altmann SA (1956) Avian mobbing behavior and predator recognition. Condor 58:241-253

Boulinier T, Nichols JD, Sauer JR, Hines JE, Pollock KH (1998) Estimating species richness: the importance of heterogeneity in species detectability. Ecology 79:1018-1028

Burgas D, Byholm P, Parkkima T (2014) Raptors as surrogates of biodiversity along a landscape gradient. J Appl Ecol 51:786-794

Caro TM (2005) Antipredator defenses in birds and mammals. University Chicago Press, Chicago

Cawthorn JM, Morris DL, Ketterson ED, Nolan V (1998) Influence of experimentally elevated testosterone on nest defence in Dark-eyed Juncos. Anim Behav 56:617-621

Chandler CR, Rose RK (1988) Comparative analysis of the effects of visual and auditory stimuli on avian mobbing behavior. J Field Ornithol 59:269-277

Consla DJ, Mumme RL (2012) Response of captive raptors to avian mobbing calls: the roles of mobber size and raptor experience. Ethology 118:1-9

Courter JR, Ritchison G (2010) Alarm calls of tufted titmice convey information about predator size and threat. Behav Ecol 21:936-942

Curio E (1978) The adaptive significance of avian mobbing. I Teleonomic hypotheses and predictions. Z Tierpsychol 48:175-183

Donázar JA, Hiraldo F, Delibes M, Estrella RR (1989) Comparative food habits of the Eagle Owl Bubo bubo and the Great Horned Owl Bubo virginianus in six Palearctic and Nearctic biomes. Ornis Scand 20:298-306

Dugatkin LA, Godin JGJ (1992a) Predator inspection, shoaling and foraging under predation hazard in the Trinidadian Guppy, Poecilia reticulata. Environ Biol Fishes 34:265-276

Dugatkin LA, Godin JGJ (1992b) Prey approaching predators: a costbenefit perspective. Ann Zool Fenn 29:233-252

Dutour M, Léna JP, Lengagne T (2017) Mobbing calls: a signal transcending species boundaries. Anim Behav 131:3-11

Flasskamp A (1994) The adaptive significance of avian mobbing V. An experimental test of the 'Move On' hypothesis. Ethology 96:322-333

Frankenberg E (1978) The adaptive significance of avian mobbing: IV. "Alerting others" and "Perception advertisement" in Blackbirds facing an Owl. Z Tierpsychol 55:97-118

Gehlbach FR, Leverett JS (1995) Mobbing of Eastern Screech-Owls: predatory cues, risk to mobbers and degree of threat. Condor 97:831-834

Gunn JS, Desrochers A, Villard MA, Bourque J, Ibarzabal J (2000) Playbacks of mobbing calls of Black-Capped Chickadees as a method to estimate reproductive activity of forest birds. J Field Ornithol 71:472-483
Hendrichsen DK, Christiansen P, Nielsen EK, Dabelsteen T, Sunde P (2006) Exposure affects risk of an owl being mobbed: experimental evidence. J Avian Biol 37:13-18

Jenkins J, Simmons RE, Curtis O, Atyeo M, Raimondo D, Jenkins AR (2013) The value of the Black Harrier Circus maurus as a predictor of biodiversity in the plant-rich Cape Floral Kingdom, South Africa. Bird Conserv Int 23:66-77

Kéry M, Royle JA, Schmid H (2008) Importance of sampling design and analysis in animal population studies: a comment on Sergio. J Appl Ecol 45:981-986

Knight RL, Temple SA (1986) Why does intensity of avian nest defense increase during the nesting cycle? Auk 103:318-327

Krams I, Krama T (2002) Interspecific reciprocity explains mobbing behaviour of the breeding Chaffinches, Fringilla coelebs. Proc R Soc B 269:2345-2350

Langham GM, Thomas A, Sieving C, Sieving KE (2006) Why pishing works: Titmouse (Paridae) scolds elicit a generalized response in bird communities. Écoscience 13(4):485-496. https://doi. org/10.2980/1195-6860(2006)13[485:WPWTPS]2.0.CO;2

Martín B, Ferrer M (2013) Assessing biodiversity distribution using diurnal raptors in Andalusia, southern Spain. Ardeola 60:15-28

Montgomerie RD, Weatherhead PJ (1988) Risks and rewards of nest defence by parent birds. Q Rev Biol 63:167-187

Ostreiher R (2003) Is mobbing altruistic or selfish behaviour? Anim Behav 66:145-149

Ozaki K, Isono M, Kawahara T, Iida S, Kudo T, Fukuyama K (2006) A mechanistic approach to evaluation of umbrella species as conservation surrogates. Conserv Biol 20:1507-1515

Pavey CR, Smyth AK (1998) Effects of avian mobbing on roost use and diet of Powerful Owls, Ninox strenua. Anim Behav 55:313-318

Pettifor AR (1990) The effects of avian mobbing on a potential predator, the European Kestrel, Falco tinnunculus. Anim Behav 39:821-827

Pitman RL, Deecke VB, Gabriele CM, Srinivasan M, Black N, Denkinger J, Durban JW, Mathews EA, Matkin DR, Neilson JL, Schulman-Janiger A, Shearwater D, Stap P, Ternullo R (2017) Humpback Whales interfering when mammal-eating killer whales attack other species: mobbing behavior and interspecific altruism? Mar Mamm Sci 33:7-58

Randler C, Förschler MI (2011) Heterospecifics do not respond to subtle differences in chaffinch mobbing calls-message is encoded in number of elements. Anim Behav 82:725-730

Roth T, Weber D (2008) Top predators as indicators for species richness? Prey species are just as useful. J Appl Ecol 45:987-991

Sandoval L, Wilson DR (2012) Local predation pressure predicts the strength of mobbing responses in tropical birds. Curr Zool 58:781-790

Sergio F, Newton I, Marchesi L, Pedrini P (2006) Ecologically justified charisma: preservation of top predators delivers biodiversity conservation. J Appl Ecol 43:1049-1055

Sergio F, Newton I, Marchesi L (2008) Top predators and diodiversity: much debate, few data. J Appl Ecol 45:992-999

Shields WM (1984) Barn Swallow mobbing: self-defence, collateral kin defence, group defence, or parental care? Anim Behav 32:132-148

Slagsvold T (1982) Clutch size variation in passerine birds: the nest predation hypothesis. Oecologia 54:159-169

Slagsvold T (1984) The mobbing behaviour of the Hooded Crow Corvus Corone Coronix: anti-predator defence or self-advertisement? Fauna Norv Ser C Cinclus 7:127-131

Smith NG (1969) Provoked release of mobbing - a hunting technique of Micrastur falcons. Ibis 111:241-243

Sordahl TA (1990) The risks of avian mobbing and distraction behavior: an anecdotal review. Wilson Bull 102:349-352 
Sunde P, Bolstad MS, Desfor KB (2003) Diurnal exposure as a risk sensitive behaviour in Tawny Owls Strix aluco? J Avian Biol 34:409-418

Templeton CN, Greene E (2007) Nuthatches eavesdrop on variations in heterospecific chickadee mobbing alarm calls. PNAS 104:5479-5482

Trivers R (1971) The evolution of reciprocal altruism. Q Rev Biol 46:35-57

Tryjanowski P, Morelli F, Kwieciński Z, Indykiewicz P, Møller AP (2018) Birds respond similarly to taxidermic models and live cuckoos Cuculus canorus. J Ethol 36:243-249

Turcotte Y, Desrochers A (2002) Playbacks of mobbing calls of Blackcapped Chickadees help estimate the abundance of forest birds in winter. J Field Ornithol 73:303-307

\section{Affiliations}

\section{Paulina Pawlak $^{1}$ (D) Zbigniew Kwieciński $^{2} \cdot$ Jan Hušek ${ }^{3,4}$}

4 Paulina Pawlak

paulina.pawlak92@gmail.com

1 Departament of Zoology, Faculty of Veterinary Medicine and Animal Science, University of Life Sciences, Wojska Polskiego 28, 60-637 Poznan, Poland

2 Department of Avian Biology and Ecology, Faculty of Biology, Adam Mickiewicz University, Umultowska 89, 61-614 Poznan, Poland
Winkler D (1994) Anti-predator defense by neighbors as a responsive amplifier of parental defense in Tree Swallows. Anim Behav 47:595-605

Zimmerling JR, Ankney CD (2000) A technique that increases detectability of passerine species during point counts. J Field Ornithol 71:638-649

Publisher's Note Springer Nature remains neutral with regard to jurisdictional claims in published maps and institutional affiliations.
3 Department of Biology, Faculty of Science, University of Hradec Králové, Rokitanského 62, Hradec Králové, Czech Republic

4 National Museum, Václavské Náměstí 68, 11579 Prague, Czech Republic 